\title{
MICRO SPRAY AND END CAPS PERFORMANCE OPERATING WITH WATER CONTAINING DIFFERENT CONCENTRATIONS OF ORGANIC MATTER
}

\author{
DESEMPENHO DE MICRO SPRAY E VÁLVULA FIM DE LINHA OPERANDO COM \\ ÁGUAS CONTENDO DIFERENTES CONCENTRAÇÕES DE MATERIAL ORGÂNICO
}

\author{
Fernando França da CUNHA ${ }^{1}$; Thiago Ramos da SILVA² Fernando Fagner MAGALHÃES $^{2}$; \\ Daniel de Andréa FERREIRA ${ }^{2}$; Simone Quintão SILVA ${ }^{3}$ \\ 1. Universidade Federal de Viçosa, Departamento de Engenharia Agrícola, Viçosa, MG, Brasil. fernando.cunha@ufv.br; 2. \\ Universidade Federal de Mato Grosso do Sul, Campus de Chapadão do Sul, Chapadão do Sul, MS, Brasil; 3. Universidade Estadual \\ Paulista "Júlio de Mesquita Filho", Instituto de Biociências, Letras e Ciências Exatas, São José do Rio Preto, SP, Brasil.
}

\begin{abstract}
Recently a micro spray and an end cap with drain valve device were launched on the market. Their main advantage is the low cost. The micro spray provides a higher percentage of irrigated area relative to the drippers and an end cap with drain valve removes all air from the pipes and minimizes obstructions of the emitters. However, these components need to be tested operating with different water quantities and qualities. Therefore, this study aimed to evaluate the performance of this micro spray and end cap with drain valve operating with water containing different concentrations of total solids. The experiment was conducted in a split plot scheme, with two end caps in the plots (conventional and with drain valve) and five total solid concentrations in the subplots $\left(7 \mathrm{mg} \mathrm{L}^{-1}, 407 \mathrm{mg} \mathrm{L}^{-1}, 1007\right.$ $\mathrm{mg} \mathrm{L}^{-1}, 2007 \mathrm{mg} \mathrm{L}^{-1}$ and $4007 \mathrm{mg} \mathrm{L}^{-1}$ ) in a completely randomized design, with three replications. Sixty evaluations of the irrigation system were performed and the emitters were evaluated every application of $60 \mathrm{~L}$ up to a volume of $3.6 \mathrm{~m}^{3}$. The water flow rate and application uniformity were evaluated through distribution uniformity (DU) and statistical uniformity $\left(\mathrm{U}_{\mathrm{S}}\right)$ coefficients. The micro spray performance was not affected by water application containing total solid concentrations below 270 and $500 \mathrm{mg} \mathrm{L}^{-1}$ in irrigation systems equipped with conventional end caps or with drain valves, respectively. Irrigation systems equipped with end caps with drain valve provided a better performance of micro sprays when operating with water containing total solid concentrations greater than $407 \mathrm{mg} \mathrm{L}^{-1}$. These end caps did not provided difference in micro spray performance when operating with public water.
\end{abstract}

KEYWORDS: Drip irrigation. Total solids. Application uniformity.

\section{INTRODUCTION}

The world's population is rapidly growing, and the development in agricultural does not follow the same pace (FERNANDES et al., 2013) causing worries regarding food security. Irrigation is a good alternative to increase agricultural productivity. However, it is responsible for consuming about $70 \%$ of global water resources (PAZ et al., 2002). Regarding the importance of saving water and avoid environmental damage, Barboza et al. (2013) report that drip irrigation is an efficient and economical practice, which is feasible due to the low water and energy consumption.

Paz et al. (2002) found that the higher the cost of the water, the lesser the amount that should be applied to maximize the economic return, and the greater the need to have an efficient irrigation system, which promotes better water distribution, hence better water conservation.

In this context, the aim is to use systems with a high efficiency and application uniformity in order to obtain maximum water conservation, since improper application generates a higher production cost. Drip irrigation has great advantage in this point; among all methods, it has the best efficiency in water application for agricultural production.

The water used for irrigation comes from several sources, hence different characteristics (ALMEIDA, 2010). Most water used for crop irrigation comes from surface sources (rivers, lakes or artificial reservoirs) and these sources are rich in solid contaminants, organic and non-organic, therefore, to know the water source quality is extremely important for guidance in irrigation practices and crop selections that best suited this practice.

Regarding the irrigation system design, especially in a micro-sprinkler system, some components must be considered, such the emitters and end caps. Therefore, some companies are bringing to the market end caps with drain valves and micro spray emitters, both inexpensive.

These end caps with drain valves aim to normalize irrigation systems, removing all the air from the pipes and preventing negative pressure inside the pipes avoiding collapsing and impurities suction into the emitters. When drip irrigation 
systems are turned off, the lower points continue to operate by gravity. Therefore, the air comes into the pipes through the emitters at higher points. When this system is reconnected, the air contained in the pipes is not expelled, and causes malfunction of the emitters. Moreover, when the system is shut down occurs an aspiration of debris into the emitters through the higher points, if they are in direct contact with the ground.

These end caps with drain valves solve both problems, it closes only when all the air is eliminated from the system, and flows the water from the pipes when the system is turned off, avoiding the aspiration of debris into the emitters. Moreover, it is natural that debris that may enter the system and accumulate in the line endings, thus these end caps with drain valves ensure the removal of such impurities constantly removing part of the water before and after an irrigation event.

The micro spray is an emitter that uses low operating pressure, providing water and energy conservation. However, this emitter has a low nozzle diameter, which may result in susceptibility to obstructions if operating with water containing high concentrations of total solids. However, there are no studies to confirm this fact. Therefore, this study aimed to evaluate the performance of micro sprays and end caps with drain valves operating with water containing different concentrations of total solids.

\section{MATERIAL AND METHODS}

The experiment was conducted in the experimental area of the Mato Grosso do Sul Federal University, campus Chapadão do Sul, in a split plot scheme, with two end caps in the plots (conventional and with drain valve) and five total solid concentrations in the subplots $\left(7 \mathrm{mg} \mathrm{L}^{-1}, 407\right.$ $\mathrm{mg} \mathrm{L}^{-1}, 1007 \mathrm{mg} \mathrm{L}^{-1}, 2007 \mathrm{mg} \mathrm{L}^{-1}$ and $4007 \mathrm{mg} \mathrm{L}^{-1}$ ) in a completely randomized design, with three replications. The solids were took from the first layer of the soil $(1 \mathrm{~cm})$, rich in organic matter, which were air dried and sieved in a 32 mesh steel sieve.

The test platform for irrigation water application were assembled (Figure 1), containing lateral lines equipped with conventional end caps and with end caps with drain valves. Each lateral line presented $12 \mathrm{~m}$ long, with flexible polyethylene pipes with a diameter of $16.3 \mathrm{~mm}$, equipped with micro sprays spaced $25 \mathrm{~cm}$ between emitters. The flow rate used was approximately $14 \mathrm{~L} \mathrm{~h}^{-1}$ and the pressure operation $98 \mathrm{kPa}$.

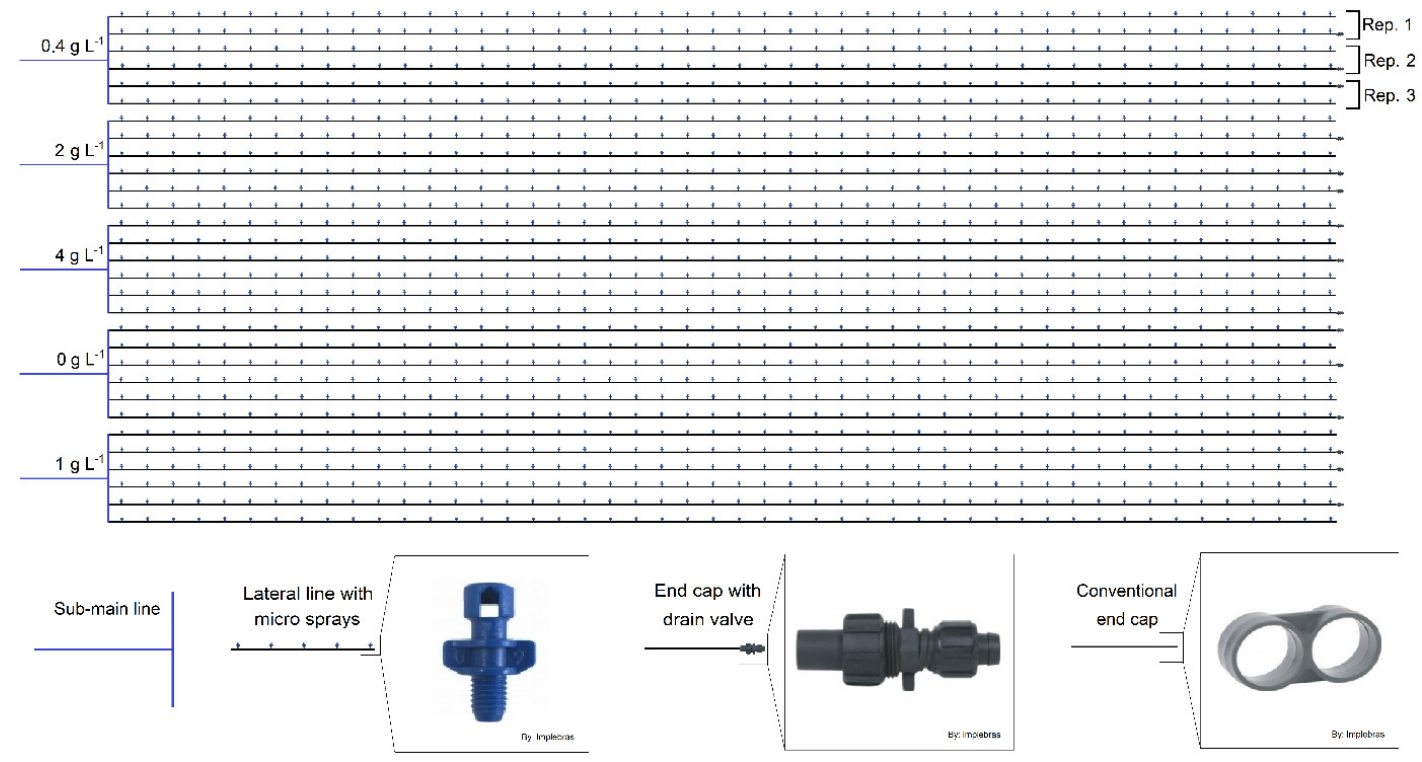

Figure 1. Sketch the experimental area and detail the micro spray, conventional end cap and end cap with drain valve. Chapadão do Sul City, Brazil, UFMS-CPCS, 2012-2014.

Sixty assessments of the irrigation system were carried out between September 27, 2012 and March 15, 2014. Irrigation were usually performed twice a week and evaluations were performed after application of 60 liters per emitter. The flow of 48 emitters per lateral line were collected. The flow rate of each emitter was obtained by a ratio between the volume collected in the emitter and the collection time.

The flow data collected allowed calculating the water application uniformity through the distribution uniformity (CRIDDLE et al., 1956) and 
statistical uniformity (WILCOX \& SWAILES, 1947) coefficients, using Equations 1 and 2, respectively.

$$
\begin{aligned}
& D U=100 \frac{d_{25 \%}}{\bar{d}} \\
& U_{S}=100\left[1-\frac{S_{d}}{\bar{d}}\right]
\end{aligned}
$$

where: $D U=$ distribution uniformity $(\%) ; d_{25 \%}=$ mean of the lowest one-quarter of the measured depths (mm); $\bar{d}=$ mean application depth (mm); $U_{S}$ $=$ statistical uniformity coefficient $(\%)$ and $S_{d}=$ standard deviation of application depth (mm).

The potential hydrogen $(\mathrm{pH})$, total dissolved $\left(\mathrm{mg} \mathrm{L}^{-1}\right)$ and suspended $\left(\mathrm{mg} \mathrm{L}^{-1}\right)$ solids of the irrigation water were evaluated in the different treatments at the Soils Laboratory of the CPCS/UFMS. The gravimetric methodology was used to measure the dissolved and suspended solids, according to APHA (1999).

Microbiological analyzes were performed at the Microbiology Laboratory of Ibilce/Unesp (São José do Rio Preto-SP). A micro spray from each replicate was randomly selected and homogenized in a saline solution $(0.9 \%)$. Afterwards, successive dilutions and plating through the spread plate technique were performed. The plates were incubated in an oven at $37^{\circ} \mathrm{C}$ for $24 \mathrm{~h}$, and the number of colony forming units $\left(\mathrm{CFU} \mathrm{mL} \mathrm{L}^{-1}\right)$ was counted.

The data were submitted to variance and regression analysis and the means were compared using the Tukey test at 0.05 significance. The models chosen for quantitative factors were based on the significance of the regression coefficients using the " $\mathrm{t}$ " test at 0.05 probability, on the determination coefficient $\left(\mathrm{R}^{2}=\right.$ Regression $\mathrm{SQ} / \mathrm{SQ}$ treatment) and on the biosystemic phenomenon. The statistical analysis were carrying out with the statistical programs "Assistat 7.6" and "Sigma Plot 11.0”.

\section{RESULTS AND DISCUSSION}

Regardless the total solids concentration in the irrigation water, the $\mathrm{pH}$ did not exceed 5.74 (Table 1), contributing to a moderate obstruction risk (CAPRA; SCICOLONE, 1998). The bacterial population among the treatments with total solids concentrations of 7 and $4007 \mathrm{mg} \mathrm{L}^{-1}$ increased 10212.2\%. According to Nakayama \& Bucks (1991), applying water treatments with concentrations of 2007 and $4007 \mathrm{mg} \mathrm{L}^{-1}$ of total dissolved solids presented moderate obstruction risk and other treatments presented low risk; the suspended solids presented low obstruction risk with public water and other treatments severe risk.

Table 1. Average values of hydrogen potential (pH), bacterial population (BP) and total dissolved solids (TDS) and total suspended solids (TSS) in irrigation water collected on issuers of different treatments. Chapadão do Sul City, Brazil, UFMS-CPCS, 2012-2014

\begin{tabular}{lccccc}
\hline Treatment $\left(\mathrm{mg} \mathrm{L}^{-1}\right)$ & 7 & 407 & 1007 & 2007 & 4007 \\
\hline $\mathrm{pH}$ & 5.91 & 5.93 & 5.78 & 5.85 & 5.74 \\
$\mathrm{BP}(\mathrm{CFU} \mathrm{mL}$ & -1 & & & \\
TDS $\left(\mathrm{mg} \mathrm{L}^{-1}\right)$ & $7.70_{\mathrm{x}} 10^{2}$ & $2.04_{\mathrm{x}} 10^{3}$ & $2.72_{\times} 10^{3}$ & $2.27_{\mathrm{x}} 10^{3}$ & $7.86_{\mathrm{x}} 10^{4}$ \\
TSS $\left(\mathrm{mg} \mathrm{L}^{-1}\right)$ & 7 & 185 & 395 & 623 & 988 \\
\hline
\end{tabular}

The water volume accumulation and the total solids increase reduced the micro spray flow (Figure 2). The flow reduction was higher in treatments with higher total solids concentrations. According to the regression equation, the flow rate differences in the micro spray irrigation system equipped with conventional end caps, from the beginning $(0 \mathrm{~L})$ to the end $(3600 \mathrm{~L})$ of the experimental period, were 5.8 and $60.3 \%$ in treatments with 7 and $4007 \mathrm{mg} \mathrm{L}^{-1}$ of total solids, respectively. According to the regression equations, the irrigation system equipped with end caps and drain valves had differences in the micro spray flow between the beginning and end of the experimental period in treatments with $7 \mathrm{mg} \mathrm{L}^{-1}(0.1 \%)$ and 4007 $\mathrm{mg} \mathrm{L}^{-1}(52.3 \%)$ of total solids.
The results indicated that the total solids concentrations were harmful to the micro sprays. The large reduction in flow was due to the small size of the micro spray nozzles, approximately 0.5 $\mathrm{mm}$. This data confirms the classification data of emitter's nozzle size regarding the obstruction sensitivity, proposed by Pizarro Cabelo (1996). Souza et al. (2008) evaluating micro-sprinklers with $0.90 \mathrm{~mm}$ nozzles, found that cattle and poultry wastewater had $1544 \mathrm{mg} \mathrm{L}^{-1}$ of total solid concentrations causing emitter obstructions, while emitters with diameter of $1.8 \mathrm{~mm}$ were not obstructed with concentrations of $1863 \mathrm{mg} \mathrm{L}^{-1}$, showing the positive influence of obstruction by reducing the size of the emitters nozzle. 

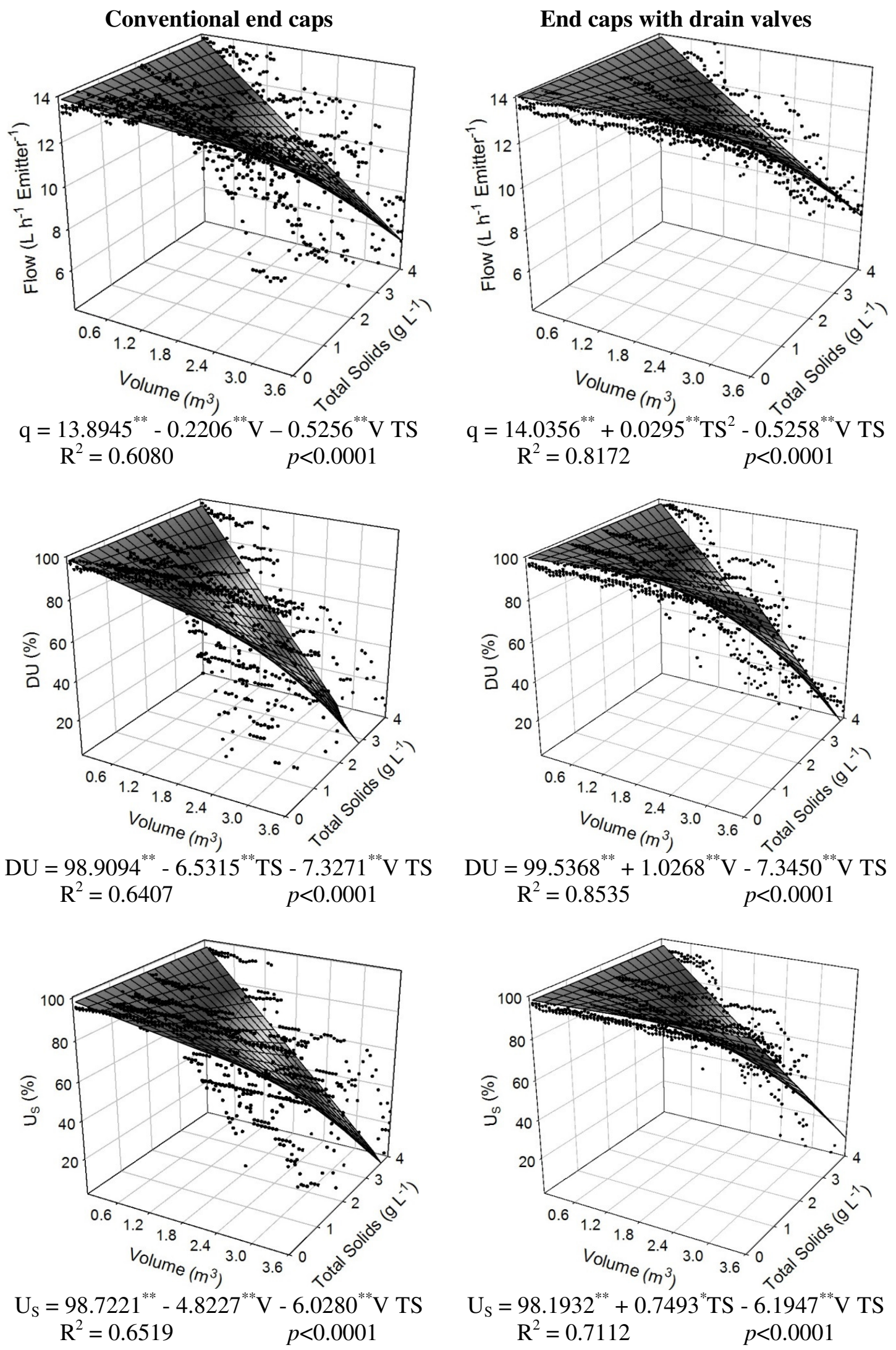

Figure 2. Micro spray flow (q) and distribution uniformity (DU) and statistical uniformity $\left(\mathrm{U}_{\mathrm{S}}\right)$ coefficients at different concentrations of total solids (TS) and volume (V) applied to systems equipped with conventional end caps and end caps with drain valves. Chapadão do Sul City, Brazil, UFMS-CPCS, 2012-2014. 
Accepting a maximum reduction of $10 \%$ in the final flow of the application accumulating 3600 $\mathrm{L}$, the water in irrigation systems equipped with conventional end caps and end caps with drain valves could have maximum concentrations of 314.7 and $750.4 \mathrm{mg} \mathrm{L}^{-1}$ of total solids, respectively, according to the regression equation. These results confirms the Nakayama \& Bucks (1991) and Liu \& Huang (2009) studies, in which waters with concentrations greater than $100 \mathrm{mg} \mathrm{L}^{-1}$ presents severe risk of obstruction of drip emitters. Batista et al. (2013) also observed flow reduction correlated with the increase in total solids in the irrigation water, combining pure water with sewage effluent with total solids concentrations of 50, 225 and 399 $\mathrm{mg} \mathrm{L}^{-1}$, which presented flow reductions of 9,25 and $34 \%$, respectively, after 48 hours of application.

In addition to the total solids, there was microorganism growth in the emitters discharge section (Table 1) because the solids presented in the irrigation water came from organic matter with good nutrient content. Sagi et al. (1995) found an average flow reduction of $38 \%$ compared to the initial flow due to the presence of mucilage formed by protozoa colonies (Epystilys balanarum). This phenomenon was also studied in drip irrigation systems operating with water containing organic matter concentrations (RESENDE et al., 2000) and different wastewaters (BATISTA et al., 2005; CUNHA et al., 2006; SOUZA et al., 2008).

The distribution uniformity (DU) had a linear decrease in value as a function of cumulative volume of water and total solids concentration, regardless the end cap used (Figure 2). This result confirms the study of Batista et al. (2013), who also found a linear reduction of DU due to the accumulated volume of water applied by emitters Naan, Drip, Paz and Plastro Hydro PC.

Greater reductions in DU values in treatments with higher concentrations of total solids were also observed. This result may probably be associated with the physical barrier by the total solids in the emitters and by the biofilm formation caused by the bacteria interaction with the suspended solids, confirming with the findings of Vale et al. (2013).

At the beginning of the tests (September 27, 2012), all DU values of the units were higher than $90 \%$, classified as "excellent" by Merriam \& Keller (1978), which classified DU values between 80 and $90 \%$ as "good", 70 to $80 \%$ as "regular" and below $70 \%$ as "poor". The analysis of the DU values in the regression equation performed at the end of the experimental period (March 15, 2014), after the flow of $3600 \mathrm{~L}$ through the emitters, showed that only irrigation water with maximal concentrations of total solids of $270.9 \mathrm{mg} \mathrm{L}^{-1}$ (conventional end caps) and $500.7 \mathrm{mg} \mathrm{L}^{-1}$ (end cap with drain valve), DU values remained above $90 \%$, hence excellent rating.

After the application of $3600 \mathrm{~L}$ by the irrigation system, water with concentrations higher than 3005.5 (conventional end caps) and $3904.3 \mathrm{mg}$ $\mathrm{L}^{-1}$ (end cap with drain valve) of total solids presented 0\% DU. Cunha et al. (2006) using wastewater from pulping coffee fruits, with total solids concentration of $3708 \mathrm{mg} \mathrm{L}^{-1}$ observed a DU values reducing from 94 to $0 \%$ after 108 hours of operation.

When the DU is reduced, the time of water application can be increased, thus the plants receiving lower irrigation levels would receive the amount previously established in order to meet their water requirements. However, the plants receiving the proper amount or water would have problems with the excessive irrigation, with the system consuming more energy and water loss through percolation and possible nutrients leaching occurring (VALE et al., 2013). According to López et al. (1992), in micro-irrigation, the DU equation is the most used to evaluate systems, since it enables a more accurate measure, super estimating values for plants that received less water.

The emitters flow and DU results observed were similar to the statistical uniformity coefficient $\left(U_{S}\right)$, with water volume accumulation and total solids increase reducing the values, regardless the end cap used (Figure 2). According to Favetta \& Botrel (2001), irrigation systems presenting $U_{S}$ values greater than $90 \%$ are classified as "excellent", between 80 and $90 \%$ as "very good", between 70 and $80 \%$ as "regular", between 60 and $70 \%$ as "bad", and less than $60 \%$ as "unacceptable". Therefore, the system had excellent rating at the beginning of the experiment and after the flow of $3600 \mathrm{~L}$ of water with a concentration of $7 \mathrm{mg} \mathrm{L}^{-1}$ of total solids. According to the regression equation, the $\mathrm{U}_{\mathrm{S}}$ value changed from 98.2 to $98.0 \%$, still classified as "excellent", showing that the micro spray present an optimal performance operating with good quality water.

Table 2 presents that the end caps had no effect in reducing the evaluated parameters with water containing $7 \mathrm{mg} \mathrm{L}^{-1}$ in the accumulated volume of $3600 \mathrm{~L}$. In the treatment with total solids concentration of $4007 \mathrm{mg} \mathrm{L}^{-1}$, the end cap with drain valve reduced the flow at the end of the $3600 \mathrm{~L}$ application. In the other concentrations, regardless the parameter evaluated, the irrigation system 
equipped with the end cap and drain valve had

better performance.

Table 2. Reducing the micro spray flow (q) and distribution uniformity (DU) and statistical uniformity ( $\mathrm{U}_{\mathrm{S}}$ ) coefficients between the first and last irrigation, in \%, applied to systems equipped with conventional end caps and end caps with drain valves. Chapadão do Sul City, Brazil, UFMS-CPCS, 2012-2014

\begin{tabular}{cccrrrrr}
\hline \multirow{2}{*}{ Factor } & \multirow{2}{*}{ End caps } & \multirow{2}{*}{ MSD $^{*}$} & \multicolumn{5}{c}{ Total Solids Concentration $\left(\mathrm{mg} \mathrm{L}^{-1}\right)$} \\
\cline { 4 - 7 } & & 7 & 407 & 1007 & 2007 & 4007 \\
\hline $\mathrm{q}$ & Conventional & \multirow{2}{*}{14.29} & $5.40 \mathrm{a}$ & $19.02 \mathrm{a}$ & $27.36 \mathrm{a}$ & $41.85 \mathrm{a}$ & $67.41 \mathrm{a}$ \\
$\left(\mathrm{L} \mathrm{h}^{-1}\right)$ & With drain valves & & $2.86 \mathrm{a}$ & $4.58 \mathrm{~b}$ & $9.56 \mathrm{~b}$ & $24.42 \mathrm{~b}$ & $48.00 \mathrm{~b}$ \\
\cline { 1 - 5 } $\mathrm{DU}$ & Conventional & \multirow{2}{*}{23.54} & $6.03 \mathrm{a}$ & $57.87 \mathrm{a}$ & $77.10 \mathrm{a}$ & $93.87 \mathrm{a}$ & $100.00 \mathrm{a}$ \\
$(\%)$ & With drain valves & & $3.96 \mathrm{a}$ & $6.38 \mathrm{~b}$ & $19.31 \mathrm{~b}$ & $52.97 \mathrm{~b}$ & $92.87 \mathrm{a}$ \\
\hline $\mathrm{U}_{\mathrm{S}}$ & Conventional & \multirow{2}{*}{19.90} & $4.58 \mathrm{a}$ & $37.92 \mathrm{a}$ & $55.83 \mathrm{a}$ & $71.72 \mathrm{a}$ & $92.86 \mathrm{a}$ \\
$(\%)$ & With drain valves & & $2.63 \mathrm{a}$ & $4.77 \mathrm{~b}$ & $12.92 \mathrm{~b}$ & $36.51 \mathrm{~b}$ & $100.00 \mathrm{a}$ \\
\hline
\end{tabular}

* MSD - minimum significant difference. ${ }^{* *}$ For each parameter, the means followed by the same letter in each column are not significantly different using Tukey's test $(p<0.05)$.

\section{CONCLUSIONS}

The micro spray performance is not affected by water application with total solids concentrations below 270 and $500 \mathrm{mg} \mathrm{L}^{-1}$ in irrigation systems equipped with conventional end caps and end caps with drain valves, respectively.

End caps do not cause difference in micro spray performance when operating with public water.
Irrigation systems equipped with end caps provide better micro spray performance when operating with water containing total solids concentrations greater than $407 \mathrm{mg} \mathrm{L}^{-1}$.

\section{ACKNOWLEDGEMENTS}

The authors thank the Implebrás Irrigação for the irrigation equipment donation.

RESUMO: Recentemente foi lançado no mercado um micro spray e um dispositivo fim de linha autolimpante tendo como principais vantagens o baixo custo. $\mathrm{O}$ micro spray propicia maior porcentagem de área irrigada em relação aos gotejadores e o fim de linha autolimpante retiram todo o ar das tubulações e minimizam o entupimento dos emissores. Entretanto, esses componentes precisam ser testados operando com diferentes quantidades e qualidades de água. Diante disso, o presente trabalho teve como objetivo avaliar o desempenho do micro spray e da válvula autolimpante operando com águas contendo diferentes concentrações de sólidos totais. O experimento foi conduzido em esquema de parcelas subdivididas, tendo nas parcelas dois finais de linha (convencional e válvula autolimpante) e nas subparcelas cinco águas com concentrações de sólidos totais $\left(7 \mathrm{mg} \mathrm{L}^{-1}, 407 \mathrm{mg} \mathrm{L}^{-1}, 1.007 \mathrm{mg} \mathrm{L}^{-1}, 2.007 \mathrm{mg} \mathrm{L}^{-1}\right.$ e 4.007 mg L ${ }^{-1}$ ) no delineamento inteiramente casualizado (DIC), com três repetições. Foram realizadas 60 avaliações do sistema de irrigação e os emissores eram avaliados a cada aplicação de $60 \mathrm{~L}$, acumulando o volume de $3,6 \mathrm{~m}^{3}$. Os parâmetros avaliados foram a vazão e as uniformidades de aplicação de água por meio dos coeficientes de distribuição (CUD) e estatístico (CUE). O desempenho dos micros spray testados não foi afetado com aplicação de águas contendo concentrações de sólidos totais inferiores a 270 e $500 \mathrm{mg} \mathrm{L}^{-1}$ nos sistemas de irrigação equipados com finais de linha convencionais e autolimpantes, respectivamente. Sistemas de irrigação equipados com finais de linha autolimpantes proporcionam melhor desempenho dos micros spray quando operam com águas contendo concentrações de sólidos totais superiores a $407 \mathrm{mg} \mathrm{L}^{-1}$. Esses mesmos finais de linha não proporcionam diferença no desempenho dos micros spray quando operam com água de abastecimento.

PALAVRAS-CHAVE: Irrigação localizada. Sólidos totais. Uniformidade de aplicação.

\section{REFERENCES}

ALMEIDA, O. A. Qualidade da água de irrigação. Cruz das Almas: Embrapa Mandioca e Fruticultura, 2010. 227 p.

APHA. Standard methods for the examination of water and wastewater. 22. ed. Washington DC: APHA, 2012. 733p. 
BARBOZA, G. C.; HERNANDEZ, F. B. T.; FRANCO, R. A. M. Análise dos riscos à sistemas de irrigação causados pela qualidade da água do Córrego do Coqueiro-SP. Revista Brasileira de Agricultura Irrigada, Fortaleza, v. 5, n. 1, p. 24-36, 2013.

BATISTA, R. O.; MATOS, A. T.; CUNHA, F. F.; LO MONACO, P. A. Obstrução de gotejadores utilizados para a aplicação de água residuária da despolpa dos frutos do cafeeiro. Irriga, Botucatu, v. 10, n. 3, p. 299-305, 2005.

BATISTA, R. O.; OLIVEIRA, R. A.; SANTOS, D. B.; MESQUITA, F. O.; SILVA, K. B. Suscetibilidade ao entupimento de gotejadores operando com água residuária de suinocultura. Water Resources and Irrigation Management, Cruz das Almas, v. 2, n. 1, p. 19-25, 2013.

CAPRA, A.; SCICOLONE, B. Water quality and distribution uniformity in drip/trickle irrigation systems. Journal of Agricultural Engineering Research, New York, v. 70, n. 4, p. 355-365, 1998. http://dx.doi.org/10.1006/jaer.1998.0287

CRIDDLE, W. D.; DAVIS, S.; PAIR, C. H.; SHOCKLEY, D. G. Methods for evaluating irrigation systems. Washington DC: Soil Conservation Service, 1956. 24p. Agricultural Handbook, 82.

CUNHA, F. F.; MATOS, A. T.; BATISTA, R. O.; LO MONACO, P. A. Uniformidade de distribuição em sistemas de irrigação por gotejamento utilizando água residuária da despolpa dos frutos do cafeeiro. Acta Scientiarum. Agronomy, Maringá, v. 28, n. 1, p. 143-147, 2006.

http://dx.doi.org/10.4025/actasciagron.v28i1.1706

FAVETTA, G. M.; BOTREL, T. A. Uniformidade de sistemas de irrigação localizada: Validação de equações. Scientific Agricultural, Piracicaba, v. 58, n. 2, p. 427-430, 2001. http://dx.doi.org/10.1590/S010390162001000200030

FERNANDES, D. A.; GOBBO, S. D. A.; SUHET, M. I.; AMARAL, A. A. Uso da água e sustentabilidade da agricultura. Revista Verde de Agroecologia e Desenvolvimento Sustentável, Mossoró, v. 8, n. 5, p. 101-107, 2013.

LIU, H.; HUANG, G. Laboratory experiment on drip emitter clogging with fresh water and treated sewage effluent. Agricultural Water Management, Beijin, v. 96, n. 5, p. 745-756, 2009.

http://dx.doi.org/10.1016/j.agwat.2008.10.014

LÓPEZ, J. R.; ABREU, J. M. H.; REGALADO, A. P.; HERNÁNDEZ, J. F. G. Riego localizado. Espana: Mundi Prensa, 1992. 405p.

MERRIAM, J. L., KELLER, J. Farm irrigation system evaluation: A guide for management. Logan: Utah State University, 1978. 271p.

NAKAYAMA, F. S.; BUCKS, D. A. Emitter clogging effects on trickle irrigation uniformity. Transaction of the ASAE, St. Joseph, v. 24, n. 1, p. 77-80, 1991. http://dx.doi.org/10.13031/2013.34203

PAZ, V. P. S.; FRIZZONE, J. A.; BOTREL, T. A.; FOLEGATTI, M. V. Otimização do uso da água em sistemas de irrigação por aspersão. Revista Brasileira de Engenharia Agrícola e Ambiental, Campina Grande, v. 6, n. 3, p. 404-408, 2002. http://dx.doi.org/10.1590/S1415-43662002000300004

PIZARRO CABELLO, F. Riegos localizados de alta frecuencia. 3. ed. Madrid: Mundi Prensa, 1996. 513p.

RESENDE, R. S.; COELHO, R. D.; PIEDADE, S. M. S. Suscetibilidade de gotejadores ao entupimento de causa biológica. Revista Brasileira de Engenharia Agrícola e Ambiental, Campina Grande, v. 4, n. 3, p. 368 375, 2000. http://dx.doi.org/10.1590/S1415-43662000000300011 
SAGI, G.; PAZ, E.; RAVINA, I; SCHISCHA, A.; MARCU, A.; YECHIELY, Z. Clogging of drip irrigation systems by colonial protozoa and sulfur bacteria. In: International Microirrigation Congress, 5., Orlando, 1995. Proceedings... St. Joseph: ASAE, 1995. p.250-254.

SOUZA, J. A. R.; BATISTA, R. O.; FERREIRA, P. A.; MOREIRA, D. A.; FERREIRA, D. C. Alteração na vazão de micro aspersores operando com água residuária de galinhas poedeiras. Engenharia na Agricultura, Viçosa, v. 16, n. 1, p. 57-64, 2008.

VALE, H. S. M.; ARRUDA, L. E. V.; COSTA, D. O.; COSTA, F. G. B.; BATISTA, R. O. Potencial de entupimento de um sistema de irrigação por gotejamento operando com esgoto doméstico tratado. Water Resources and Irrigation Management, Cruz das Almas, v. 2, n. 1, p. 63-70, 2013.

WILCOX, J. C.; SWAILES, G. E. Uniformity of water distribution by some under tree orchard sprinklers. Scientific Agriculture, Ottawa, v. 27, n. 11, p. 565-583, 1947. 